ISBN 978-81-933894-1-6

5th International Conference on Chemical, Agricultural, Biological and Environmental Sciences

(CAFES-17)

Kyoto (Japan) April 18-19, 2017

\title{
Color and Chemical Oxygen Demand (COD) Removal by Bacteria Consortium Using Factorial Design
}

\author{
Nur Hanis Mohamad Hanapi ${ }^{1}$, Sharifah Hanis Yasmin Sayid Abdullah, ${ }^{1}$ Che Noraini Che Hasnam ${ }^{1}$ \\ Zuriati Khairuddin ${ }^{1}$, Zarizal Suhaili ${ }^{2}$, Azizah Endut ${ }^{1,3}$, and Hafizan Juahir ${ }^{1}$ \\ ${ }^{1}$ East Coast Environmental Research Institute, UniSZA \\ ${ }^{2}$ Faculty of Biotechnology and Food Industry, UniSZA \\ ${ }^{3}$ Faculty of Innovative Design and Technology, University Sultan Zainal Abidin (UniSZA), 21300 Kuala \\ Terengganu, Malaysia
}

\begin{abstract}
The present study is focused on the effect of bacteria consortium in removing color and reducing chemical oxygen demand (COD) in the textile dye wastewater. There were three bacterial isolated involved in this study namely $\mathrm{Cl}, \mathrm{C} 3 \mathrm{~W}$ and C3K. Factorial design was applied into this study with five factors to be observed. They were $\mathrm{pH}$, initial bacterial consortium concentration, temperature, agitation and aeration. Following seven days of incubation period, it was observed that the chemical oxygen demand removal was achieved from $79.21 \%$ to $86 \%$ in the designated process conditions whilst decolorization occurred from $32.27 \%$ up to $52.74 \%$. The highest decolorization achieved was $52.74 \%$ with $15 \%$ of bacterial inoculum, low initial $\mathrm{pH}$ and no aeration present while highest chemical oxygen demand removal (86\%) was achieved with high initial $\mathrm{pH}$, low initial bacterial inoculum and no aeration present during the incubation period.
\end{abstract}

Keywords: Textile dye wastewater, color removal, COD reduction, bacteria consortium, factorial design

\section{Introduction}

Textile industries are one of the major factors that contribute to the water pollution with the textile wastewater production $[1,3-4,8,21]$. Textile wastewater is a toxic discharge from textile industry, which contains colouring agents that can cause danger to the environment, especially the water bodies such as river, ponds, lakes and sea [20]. Synthetic dyes are widely utilized in textile, paper-made, dyeing and other industries leading to a large-scale development of dye industries [22]. Dyes are most hazardous chemical compound classes found in industrial effluents which need to be treated since their presence in water bodies reduce light penetration, precluding the photosynthesis of aqueous flora [2]. Dye removal is an important but challenging area of wastewater treatment because some dyes and their degradation products may be carcinogenic and toxic to animals $[9,18]$. It is characterized by strong colour, high salinity, high temperature, variable $\mathrm{pH}$ and high chemical oxygen demand (COD) [10]. Recently, global economic prosperity has caused rapid growth and extensive development of the textile industry. Over 100, 000 dyes has been synthesized worldwide and more than 700,000 tonnes are produced annually. More than 10,000 dyes are commercially available, but over 5\% is discharged into aquatic environments by plants and users [5]. Wide application of biological treatments since it is cost-effective, reduce energy usage and environmental friendly [1, 8, 14]. Azo dyes are used for producing majority of textile dyestuffs and also synthetic formulations in many industries [10]. Azo dyes are the most widely used dyes and represent over $60 \%$ of the total dyes [14]. Textile dyes and finishing wastewater is known 
to contain strong colour, high $\mathrm{pH}$, temperature and COD and low biodegradability [19]. Anoxic or anaerobic hydrolysis-acidification process could not only remove the colour and a portion of the chemical oxygen demand (COD) [26]. The azo and other chromophoretic groups in the dye matrix render geno toxicity to the biodiversity in the environment [7]. Color is usually the first contaminant to be recognized in wastewater. The discharge of less than $1 \mathrm{ppm}$ for some dyes is aesthetically displeasing, which impedes light penetration, and affecting gas solubility thus damaging the quality of the receiving streams and may be toxic to microorganisms utilized in the treatment processes, to food chain organisms and to aquatic life [17].

The study is aimed to observe the color and chemical oxygen demand (COD) removal as well as isolation and identification of environmental microbes that are capable in performing the tasks. In this study a complete biological treatment process is applied under certain parameters in order to determine the best process condition for these potential microbial isolates in order to remove color and chemical oxygen demand from the textile dye effluent. The process conditions that to be examined include $\mathrm{pH}$, temperature, bacterial inoculums concentrations, agitation speed, aeration and initial dye concentration for the simulated dye wastewater.

\section{Materials and Methodology}

\subsection{Raw Materials}

Raw textiles wastewater used in this study was obtained from a local backyard textile industry located in Kuala Terengganu, Malaysia. The textile wastewater was stored at $4^{\circ} \mathrm{C}$ in a chiller. Bacteria consortium applied in this study was collected from activated sewage (IWK Malaysia) and have been labeled in previous screening studies. They are labeled as $\mathrm{C} 1, \mathrm{C} 3 \mathrm{~K}$ and $\mathrm{C} 3 \mathrm{~W}$ respectively. The isolates are maintained on nutrient agar (NA, Merck) and nutrient broth (NB, Merck) alternately and stored at $<3^{\circ} \mathrm{C}$ for further studies.

\subsection{Experimental procedure}

The factorial design (Stat-Ease Design Expert v7.0.0) was carried out with five factors to be studied namely $\mathrm{pH}$, concentration of bacterial inoculum, temperature, agitation and aeration. There are two levels $(-1$ and +1$)$ to be observed in the design which sum up to total eight run of experiments. The details of the factorial design can be referred in Table 1 . The initial textile wastewater was set as $150 \mathrm{ml}$, sterilized at $121^{\circ} \mathrm{C}$ and inoculated with the designed bacterial consortium concentrations (5\% and 15\%) and incubated for seven (7) days. The samples then collected and analysis of $\mathrm{pH}$ (Thermo Scientific), COD (method 435 HACH DR2800), color (method 125 HACH DR2800), total suspended solids (method 8006 HACH DR900), turbidity (HACH 2100Q01) and dissolved oxygen (YSI Multiparameter) were conducted.

\subsection{Calculation}

In reduction of chemical oxygen demand (COD), it can be calculated using the equation as follows:

COD removal $(\%)=\left[\left(\mathrm{P}_{0}-\mathrm{Pt}\right) / \mathrm{P}_{0}\right] \times 100$

Where $\mathrm{P}_{0}$ is the initial COD value, $\mathrm{Pt}$ is COD value after treatment time, $\mathrm{t}$ [25]. The calculation of color reduction also goes as follows;

Color reduction $(\%)=[(\mathrm{I}-\mathrm{F}) / \mathrm{I}] \mathrm{x} 100$

With I representing the initial absorbance of the sample, and $\mathrm{F}$ is the absorbance of decolorized sample. 
TABLE 1: Experimental design of 2-Level Factorial Design

\begin{tabular}{|c|c|c|c|c|c|c|c|}
\hline \multirow[t]{2}{*}{ Test (T) } & \multicolumn{5}{|c|}{ Variable level in coded form } & \multirow{2}{*}{$\begin{array}{c}\text { Decolorization } \\
(\%)\end{array}$} & \multirow{2}{*}{$\begin{array}{c}\text { COD Removal } \\
(\%)\end{array}$} \\
\hline & $\mathrm{X} 1(\mathrm{pH})$ & $\begin{array}{c}\mathrm{X} 2 \\
\text { ([Inoculum] } \\
(\%))\end{array}$ & $\begin{array}{c}\mathrm{X} 3 \\
(\text { Temperature } \\
\left.\left({ }^{\circ} \mathrm{C}\right)\right)\end{array}$ & $\begin{array}{c}\mathrm{X} 4 \\
\text { (Agitation } \\
\text { (RPM)) }\end{array}$ & $\begin{array}{c}\mathrm{X} 5 \\
\text { (Aeration) }\end{array}$ & & \\
\hline 1 & -1 & -1 & 1 & 1 & -1 & 47.88 & 83.14 \\
\hline 2 & -1 & 1 & -1 & -1 & 1 & 52.74 & 80.80 \\
\hline 3 & 1 & 1 & -1 & 1 & -1 & 50.43 & 79.21 \\
\hline 4 & 1 & 1 & 1 & 1 & 1 & 47.45 & 81.67 \\
\hline 5 & -1 & -1 & -1 & 1 & 1 & 32.27 & 83.61 \\
\hline 6 & -1 & 1 & 1 & -1 & -1 & 43.88 & 82.85 \\
\hline 7 & 1 & -1 & -1 & -1 & -1 & 45.04 & 86.00 \\
\hline 8 & 1 & -1 & -1 & -1 & 1 & 44.00 & 83.57 \\
\hline $\begin{array}{l}\text { Coded } \\
\text { values }\end{array}$ & $\begin{array}{l}\text { Actual } \\
\text { values }\end{array}$ & $\mathrm{X} 2$ & $\mathrm{X} 3$ & $\mathrm{X} 4$ & $\mathrm{X} 5$ & & \\
\hline-1 & $\mathrm{X} 1$ & 5 & 30 & 200 & 0 & & \\
\hline 1 & $\begin{array}{c}4.0 \\
10.0\end{array}$ & 15 & 40 & 100 & 1 & & \\
\hline
\end{tabular}

\section{Results and Discussion}

\subsection{NOVA (Analysis of Variance)}

\begin{tabular}{cccccc}
\multicolumn{5}{c}{ Table 2: ANOVA for COD Removal } \\
\hline \hline Source & $\begin{array}{c}\text { Sum of } \\
\text { Squares }\end{array}$ & $\mathrm{dF}$ & $\begin{array}{c}\text { Mean } \\
\text { Square }\end{array}$ & F-value & $\begin{array}{c}\text { p-value } \\
\text { Prob > F }\end{array}$ \\
\hline Model & 24.01 & 5 & 4.80 & 1.76 & 0.4011 \\
A: $\mathrm{pH}$ & 0.22 & 1 & 0.22 & 0.08 & 0.8043 \\
B: & 19.72 & 1 & 19.72 & 7.22 & 0.1151 \\
[noculum $]$ & & & & & \\
C: & 2.43 & 1 & 2.43 & 0.89 & 0.4455 \\
Temperature & & & & & \\
D: Agitation & 5.48 & 1 & 5.48 & 2.01 & 0.2922 \\
E: Aeration & $5.638 \mathrm{E}-003$ & 1 & $5.638 \mathrm{E}-003$ & $2.064 \mathrm{E}-003$ & 0.9679 \\
Residual & 5.46 & 2 & 2.73 & & \\
Cor Total & 29.47 & 7 & & & \\
\hline \hline
\end{tabular}

TABLE 3: ANOVA for decolorization

\begin{tabular}{cccccc}
\hline \hline Source & $\begin{array}{c}\text { Sum of } \\
\text { Squares }\end{array}$ & $\mathrm{dF}$ & $\begin{array}{c}\text { Mean } \\
\text { Square }\end{array}$ & F-value & $\begin{array}{c}\text { p-value } \\
\text { Prob > F }\end{array}$ \\
\hline Model & 112.89 & 5 & 22.58 & 0.30 & 0.8783 \\
A: $\mathrm{pH}$ & 12.84 & 1 & 12.84 & 0.17 & 0.7185 \\
B: & 64.76 & 1 & 64.76 & 0.87 & 0.4499 \\
[Inoculum] & & & & & \\
C: & $8.210 \mathrm{E}-003$ & 1 & $8.210 \mathrm{E}-003$ & $1.100 \mathrm{E}-004$ & 0.9926 \\
Temperature & & & & & \\
D: Agitation & 9.21 & 1 & 9.21 & 0.12 & 0.7588 \\
E: Aeration & 16.37 & 1 & 16.37 & 0.22 & 0.6856 \\
Residual & 149.22 & 2 & 74.61 & & \\
Cor Total & 262.10 & 7 & & &
\end{tabular}

Table 2 and 3 both shows the analysis of variance (ANOVA) of chemical oxygen demand (COD) removal and decolorization. According to both analysis, these two models are not significant since the p-value $>0.05$. 
Although the end results showed that decolorization and COD removal did occur during the process, however the interaction between the effects were not fully observed and analyzed thus resulting the insignificant models. The maximum COD removal achieved was $86.00 \%$ by experiment number 7 which was affected by the initial $\mathrm{pH}$ of 10 , initial concentration of inoculum was $5 \%, 100 \mathrm{rpm}$, temperature at $30^{\circ} \mathrm{C}$ and anaerobic process. The lowest COD removal was achieved by experiment number 3 with initial $\mathrm{pH} 10,15 \%$ concentration initial inoculum concentration, temperature at $30^{\circ} \mathrm{C}, 200 \mathrm{rpm}$ and under anaerobic process (no aeration). As for decolorization, maximum value was obtained at experiment number 2 which gives $52.74 \%$ of color removal under the condition of initial $\mathrm{pH} 4$, initial inoculum concentration $15 \%$, Temperature at $30^{\circ} \mathrm{C}, 200 \mathrm{rpm}$ and under anaerobic process while the lowest color removal was achieved by experiment number 5 with only $32.27 \%$. These explain the insignificant model of experiment obtained as the p-value $>0.05$. Final equation in terms of coded factors is described as below:

$\mathrm{COD}=+82.77+0.17 * \mathrm{~A}-1.64 * \mathrm{~B}+0.66 * \mathrm{C}-0.86 * \mathrm{D}-0.028 * \mathrm{E}$ while final equation in terms of actual factors come as

$\mathrm{COD}=+82.77227+0.17227 * \mathrm{pH}-1.63977 *[$ Inoculum $]+0.66409 * \mathrm{~T}-0.86477 *$ Agitation $0.027727 *$ Aeration.

\subsection{Main effects}

It was observed that from ANOVA, the interaction between the effects was not fully analyzed since only single effect occurred. For the optimum chemical oxygen demand removal and decolorization, each factor responded differently.
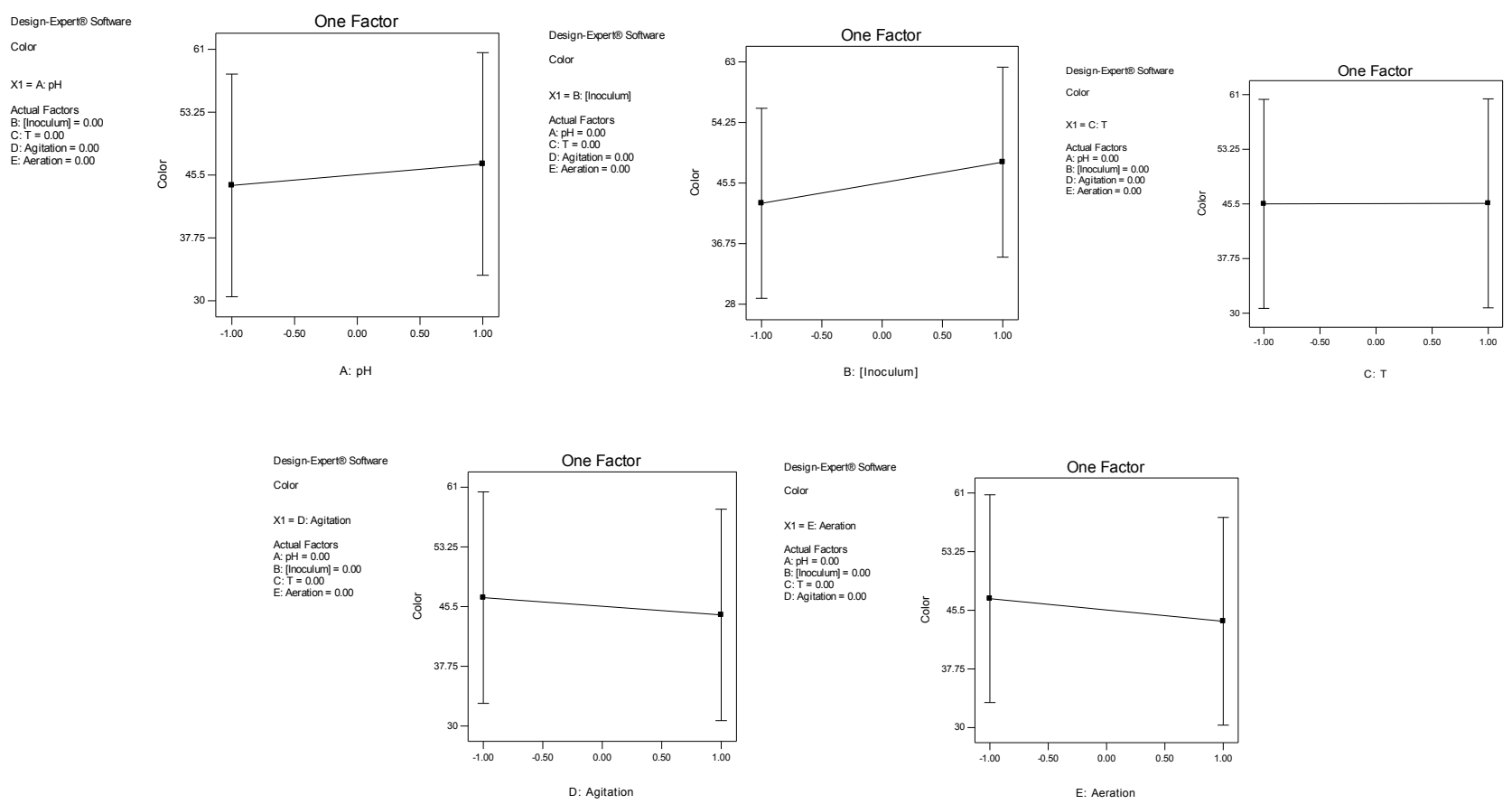

Fig 1: One factor effect for decolorization 

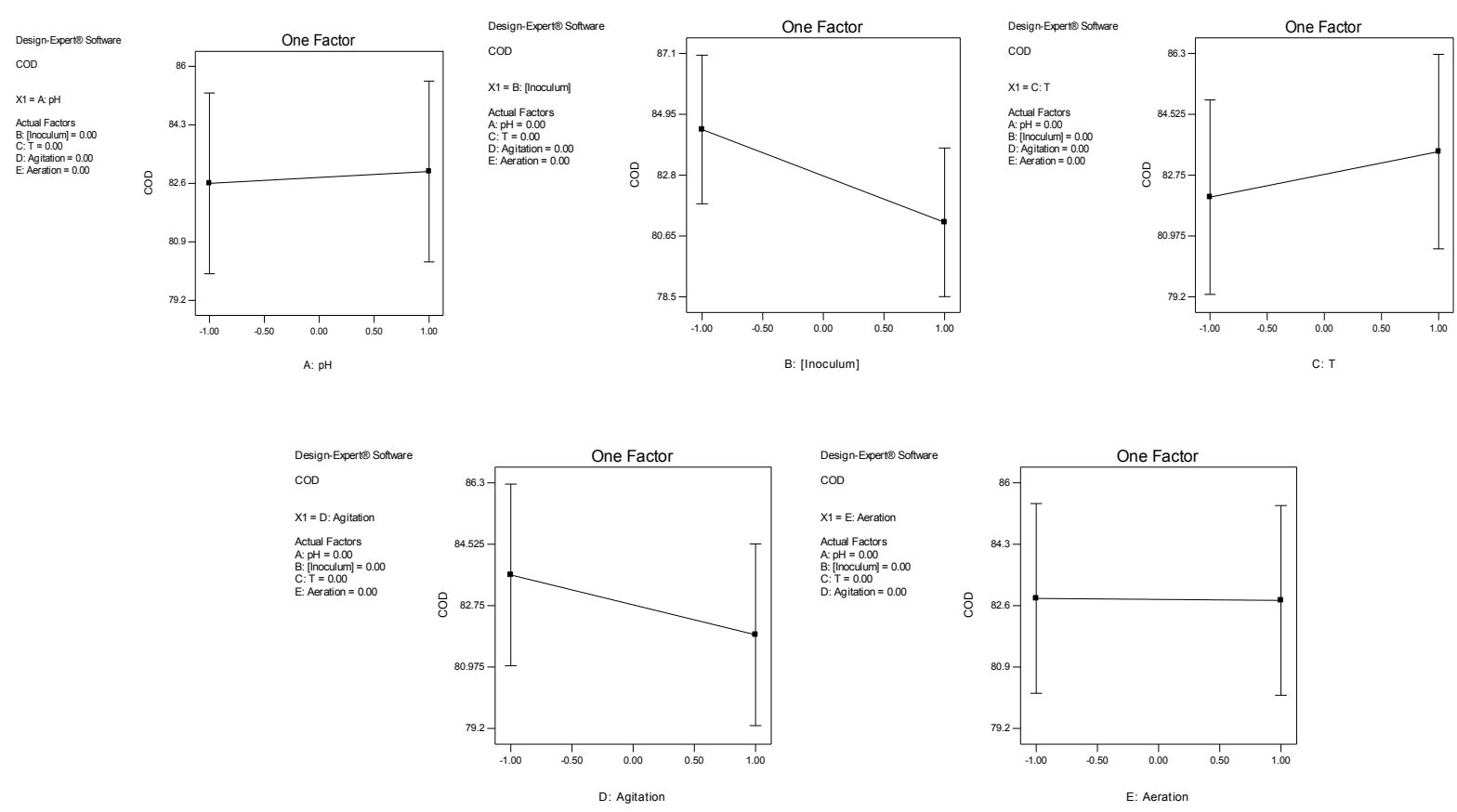

Fig. 2: One factor effect for chemical oxygen demand (COD) removal

The effects of each factor for decolorization were explained through Fig. 1. There were five factors that involved in the decolorization process which contributed to the maximum decolorization of the textile dye wastewater. Among five factors, there were factors that influenced the color removal process slightly which are factor $\mathrm{C}$ (temperature $(\mathrm{T})$ ) and factor $\mathrm{E}$ (aeration). It was observed that during the seven days of incubation period, high and low temperature did not give any significant effect to the removal of the color in the textile wastewater. Aeration also did not play major role in decolorization process as bacterial consortium was able to survive under anaerobic condition. This was proved with the maximum value of decolorozation achieved under the anaerobic condition. The most significant effect that was observed was the initial concentration of bacterial inoculum which was at high value (15\%).

Chemical oxygen demand (COD) removal was described with the single effect of each factors involved in the process. In this removal activity, initial $\mathrm{pH}(\mathrm{A})$ and aeration $(\mathrm{E})$ were not significantly affecting the removal process. This was because as can be observed in Fig. 2, there were only slight effects observed in the plot graph as compared to the other three factors (B, C and D). In COD removal, lower concentration of initial bacterial inoculum $(5 \%)$ gave a higher value of COD removal as well as low temperature during incubation period. Apparently it gave a significant effect since maximum value of COD removal is achieved $\left(\mathrm{T}\right.$ at $\left.30^{\circ} \mathrm{C}\right)$.

\section{Conclusion}

In this eight experiments conducted based on the factorial design $\left(2^{5}\right)$, the interaction between effects were not fully analyzed. The response decolorization and chemical oxygen demand (COD) removal also were affected by different factors in order to maximize the removal process. However two factors were identified which are factor $\mathrm{C}$ (temperature, $\mathrm{T}$ ) and factor $\mathrm{E}$ (aeration) that both give maximum amount of color and COD removal. It can be concluded that the bacterial consortium perform better under these anaerobic and low temperature condition.

\section{Acknowledgements}

The author would like to thank MyBrain15, Ministry of Higher Education (MOHE) Malaysia and Humid Trophic Center (HTC), Department of Irrigation and Drainage Malaysia for the support of the studies conducted. The author also would like to extend the gratitude to the fellow students of the research institute in contributing in this conducted study. 


\section{References}

[1] K. Balapure, N. Bhatt and D. Madamwar, "Mineralization of reactive azo dyes present in simulated textile wastewater using down flow microaerophilic fixed film bioreactor," Bioresour. Technol. vol. 175, pp. 1-7, October 2014. https://doi.org/10.1016/j.biortech.2014.10.040

[2] N.F. Cardoso, E.C. Lima, I.S. Pinto, C.V. Amivisca, B. Royer, R.B. Pinto, W.S. Alencar and S.F.P. Pereira, "Application of cupuassu shell as biosorbent for the removal of textile dyes from aqueous solution," J. Environ. Manage. vol. 92, pp. 1237-1247, December 2010.

https://doi.org/10.1016/j.jenvman.2010.12.010

[3] S.M.d.A.G.U. de Souza, K.A.S. Bonilla, and A.A.U de Souza, "Removal of COD and color from hydrolyzed textile azo dye combined ozonation and biological treatment," Jour. Harzard. Mat. vol. 179, pp. 35-42, February 2010. https://doi.org/10.1016/j.jhazmat.2010.02.053

[4] P.I.M. Firmino, M.E.R. da Silva, F.J. Cervantes and A.B dos Santos, "Colour removal of dyes from synthetic and real textile wastewaters in one-and-two stage anaerobic systems," Bioresour. Technol. vol. 101, pp. 7773-7779, June 2010. https://doi.org/10.1016/j.biortech.2010.05.050

[5] Z.J. Hu, Y. Xiao, D.H. Zhao, Y.L. Shen and H.W. Gao, "Preparation of dye waste-barium sulfate hybrid adsorbent and application in organic wastewater treatment," Jour. Hazard. Mater. vol. 175, pp. 179-186, October 2009. https://doi.org/10.1016/j.jhazmat.2009.09.146

[6] A.A. Kadam, H.S. Lade, D.S. Lee and S.P. Govindwar, "Zinc chloride as a coagulant for textile dyes and treatment of generated dye sludge under the solid state fermentation: hybrid treatment strategy," Bioresour. Technol. vol. 176, pp. 38-46, November 2015. https://doi.org/10.1016/j.biortech.2014.10.137

[7] S. Karthikeyan, A. Titus, A. Gnanamani, A.B. Mandal, G. Sekaran, "Treatment of textile wastewater by homogenous and heterogenous Fenton oxidation process," Desalination vol. 281, pp. 438-445, September 2011.

https://doi.org/10.1016/j.desal.2011.08.019

[8] S.L. Lim, W.L. Chu and S.M. Phang, "Use of Chlorella vulgaris for bioremediation of textile wastewater," Bioresour. Technol. vol. 101, pp. 7314-7322, May 2010.

https://doi.org/10.1016/j.biortech.2010.04.092

[9] J.F. Ma, B.Y. Cui, J. Dai and D.L. Li, "Mechanism of adsorption of anionic dye from aqueous solutions onto organobentonite," Jour. Hazard. Mater. vol. 186, pp. 1758-1765, December 2010.

https://doi.org/10.1016/j.jhazmat.2010.12.073

[10] D. Mantzavinos, and E. Psillakis, "Enhancement of biodegradability of industrial wastewaters by chemical oxidation pretreatment," J. Chem. Technol. Biotechnol. vol. 79, pp. 431-454, April 2004.

https://doi.org/10.1002/jctb.1020

[11] M. Matheswaran and T. Karunanithi, "Adsorption of Chrysoidine R by using fly ash in batch process," Jour. Hazard. Mater. vol. 145, pp. 154-161, November 2006.

https://doi.org/10.1016/j.jhazmat.2006.11.006

[12] M. Moradi and F. Ghanbari, "Application of response surface method for coagulation process in leachate treatment as pretreatment for Fenton process: Biodegradability improvement," J. Water Process. Engin. vol. 4, pp. 67-73, September 2014.

https://doi.org/10.1016/j.jwpe.2014.09.002

[13] S. Sathian, M. Rajasimman, C.S. Rathnasabapathy and C. Karthikeyan, "Performance evaluation of SBR for the treatment of dyeing wastewater by simultaneous biological and adsorption process," J. Water Process Engin. vol. 4, pp. 82-90, October 2014. 
https://doi.org/10.1016/j.jwpe.2014.09.004

[14] M. Solis, A. Solis, H.I. Perez, N. Manjarezz and M. Flores, "Microbial decolorization of azo dyes: A review," Process Biochemistry vol. 47, pp. 1723-1748, August 2012. https://doi.org/10.1016/j.procbio.2012.08.014

[15] X. Sun, C. Wang, Y. Li, W. Wang and J. Wei, "Treatment of phenolic wastewater by combined UF and NF/RO processes," Desalination. vol. 35, pp. 68-74, October 2014.

[16] M. Tichonovas, E. Krugly, V.Racys, R. Hippler, V. Kauneliene, I. Stasiulaitiene and D. Martuzevicius, "Degradation of various textile dyes as wastewater pollutants under dielectric barrier discharge plasma treatment," Chem. Engin. J. vol. 229, pp. 9-19, June 2013.

https://doi.org/10.1016/j.cej.2013.05.095

[17] S. Tilli, I. Ciullinni, A. Scozzafava and F. Briganti, "Differential decolorization of textile dyes in mixtures and the joint effect of laccase and cellobiose dehydrogenase activities present in extracellular extracts from Funalia trogii," Enzyme and Microbial Technol. vol. 49, pp. 465-471, August 2011.

https://doi.org/10.1016/j.enzmictec.2011.08.002

[18] P.C. Vandivivere, R. Bianchi and W. Verstraete, "Treatment and reuse of wastewater from the textile wet-processing industry: review of emerging technologies," J. Chem. Technol. Biotechnol. vol. 72, pp. 289-302, April 1998.

https://doi.org/10.1002/(SICI)1097-4660(199808)72:4<289::AID-JCTB905>3.0.CO;2-\#

[19] A.G. Vlyssides, D. Papaioannou, M. Loizidoy, P.K. Karlis and A.A. Zorpas, "Testing an electrochemical method for treatment of textile dye wastewater," Waste Management vol. 20, pp. 569-574, February 2000.

https://doi.org/10.1016/S0956-053X(00)00028-3

[20] P.R. Waghmare, A.A. Kadam, G.D. Saratale and S.P. Govindwar, "Enzymatic hydrolysis and characterization of waste lignocellulosic biomass produced after dye bioremediation under solid state fermentation," Bioresour. Technol. vol. 168, pp. 136-141, March 2014.

https://doi.org/10.1016/j.biortech.2014.02.099

[21] K.S. Wang, M.C. Wei, T.H. Peng, H.C. Li, S.J. Chao, T.F. Hsu, H.S. Lee and S.H. Chang, "Treatment and toxicity evaluation of methylene blue using electrochemical oxidation, fly-ash adsorption and combined electrochemical oxidation-fly ash adsorption,” Jour. Environ. Manage. vol. 91, pp. 1778-1784, March 2010. https://doi.org/10.1016/j.jenvman.2010.03.022

[22] Y.P. Wei, D.Q. Wei and H.W. Gao, "Treatment of dye wastewater by in-situ hybridization with Mg-Al layered double hydroxides and reuse of dye sludge," Chem. Engin. J. vol. 172, pp. 872-878, June 2011.

https://doi.org/10.1016/j.cej.2011.06.076

[23] A.Y. Zahrim and N. Hilal, "Treatment of highly concentrated dye solution by coagulation/flocculation-sand filtration and nanofiltration," Water Resour. Ind. vol. 3, pp. 23-34, June 2013.

https://doi.org/10.1016/j.wri.2013.06.001

[24] E. Zuriaga-Agusti, M.I. Iborra-Clar, J.A. Mendoza-Roca, M. Trancredi, M.I. Alcaina-Miranda and A. Iborra-Clar, "Sequencing batch reactor technology coupled with nanofiltration for textile wastewater reclamation," Chem. Engin. J. vol. 161, pp. 122-128, April 2010.

https://doi.org/10.1016/j.cej.2010.04.044

[25] A. Mishra and A. Malik, "Novel fungal consortium for bioremediation of metals and dyes from mixed waste stream," Bioresour. Technol. vol. 171, pp. 217-226, August 2014.

https://doi.org/10.1016/j.biortech.2014.08.047

[26] Z. Fu, Y. Zhang and X. Wang, "Textiles wastewater treatment using anoxic filter bed and biological wriggle bed ozone biological aerated filter," Bioresour. Technol. vol. 102, pp. 3748-3753, December 2010.

https://doi.org/10.1016/j.biortech.2010.12.002 